\title{
Estrogen receptor-alpha (ER-alpha) and defects in uterine receptivity in women
}

\author{
Bruce A Lessey*1, Wilder A Palomino1, KBC Apparao², Steven L Young² and \\ Ruth A Lininger ${ }^{3}$
}

\author{
Address: ${ }^{1}$ Division of Reproductive Endocrinology and Infertility, University Medical Group, Department of Obstetrics and Gynecology, Greenville \\ Hospital System, Greenville, SC, USA, ²Department of Obstetrics and Gynecology, University of North Carolina, Chapel Hill, NC, USA and \\ ${ }^{3}$ Department of Pathology and Laboratory Medicine, University of North Carolina, Chapel Hill, NC, USA \\ Email: Bruce A Lessey* - blessey@ghs.org \\ * Corresponding author
}

from Basic and applied biology of the primate reproductive tract: in honor of the career of Dr Robert M Brenner

Portland, Oregon, USA. 16-17 August 2005

Published: 9 October 2006

Reproductive Biology and Endocrinology 2006, 4(SuppI I):S9 doi:I0.II86/1477-7827-4-SI-S9

(C) 2006 Lessey et al; licensee BioMed Central Ltd.

This is an open access article distributed under the terms of the Creative Commons Attribution License (http://creativecommons.org/licenses/by/2.0), which permits unrestricted use, distribution, and reproduction in any medium, provided the original work is properly cited.

\begin{abstract}
Endometriosis is a disorder that affects $5 \%$ of the normal population but is present in up to $40 \%$ of women with pelvic pain and/or infertility. Recent evidence suggests that the endometrium of women with endometriosis exhibits progesterone insensitivity. One endometrial protein that fluctuates in response to progesterone is the estrogen receptor-alpha (ER alpha), being downregulated at the time of peak progesterone secretion during the window of implantation. Here we demonstrate that the biomarker of uterine receptivity, beta 3 integrin subunit, is reduced or absent in some women with endometriosis and that such defects are accompanied by inappropriate overexpression of ER alpha during the mid-secretory phase. Using a well-differentiated endometrial cell line we showed that the beta 3 integrin protein is negatively regulated by estrogen and positively regulated by epidermal growth factor (EGF). By competing against estrogen with various selective estrogen receptor modulators (SERMs) and estrogen receptor agonists and antagonists, inhibition of expression of the beta 3 integrin by estrogen can be mitigated. In conclusion, we hypothesize that certain types of uterine receptivity defects may be caused by the loss of appropriate ER alpha down-regulation in the mid-secretory phase, leading to defects in uterine receptivity. Such changes might be effectively treated by timely administration of the appropriate anti-estrogens to artificially block ER alpha and restore normal patterns of gene expression. Such treatments will require further clinical studies.
\end{abstract}

\section{Introduction}

Uterine receptivity is regulated by the cyclic secretion of ovarian steroids as a consequence of follicular development and subsequent ovulation. As first described in the uterus by its ability to bind estrogen [1], the classic estrogen receptor (ER-alpha), increases in response to estrogen during the proliferative phase, and is diminished in response to progesterone during the secretory phase [2]. 
Progesterone receptors (PR) undergo similar changes; we and others previously reported that expression of both ERalpha and PR are down-regulated at the time of implantation, particularly in the epithelial compartment [3-5]. While progesterone is an effective anti-estrogen, its role is to reduce ER-alpha concentration rather than to act as a competetive inhibitor of E2 binding, thereby rendering the endometrium resistant to estrogen during the window of implantation. This phenomenon has now been observed in several mammalian species [6-8].

While steroid hormones were classically described as stimulating gene expression, we now recognize from genomic studies that steroid hormones can also inhibit specific genes $[9,10]$. In endometrium, the decline in ERalpha may be a critical event, releasing an inhibitory influence on specific genes and providing a signal for endometrial receptivity to commence. The highly specialized and specific mid-secretory repertoire of endometrial gene expression coincides with a reduction in the expression of ER-alpha [10]. Based on such studies, we now suggest that the combination of progesterone action and coincident estrogen withdrawal is required to stimulate key implantation-specific events in the mid-secretory phase of the menstrual cycle.

Early implantation is a complex process involving synchronous and complementary events on both maternal and embryonic surfaces. It is now well-established that many proteins are expressed specifically at the time when embryos implant $[11,12]$. The timing of implantation has now been firmly established, occurring around 7 to 10 days after ovulation, corresponding to days 21 to 24 of an idealized 28 day menstrual cycle [13]. Integrins are one of many endometrial proteins that turn on or off around this time in a woman's cycle $[14,15]$, and the study of their patterns of expression has yielded substantial information about the factors that regulate endometrial receptivity in the human $[16,17]$. One of these integrins is the alpha v/ beta 3 integrin that is expressed on the luminal and glandular epithelium of the endometrium. Its appearance at the time of implantation and its aberrant expression in a variety of settings including luteal phase defect, endometriosis, polycystic ovarian syndrome (PCOS) and tubal disease suggests a critical role for this protein [18-21]. We recently demonstrated that the reduction in endometrial beta 3 integrin expression in PCOS was associated with elevated expression of ER-alpha and an over-expression of steroid receptor coactivators [20]. In the present report we examine the basis for this effect of estrogen on this particular marker of uterine receptivity and study women with endometriosis as another group who appear to inappropriately express high levels of ER-alpha during the window of implantation.

\section{Materials and methods \\ Patient samples}

For these studies we used endometrial samples obtained from 38 volunteers who had normal menstrual cycles and proven fertility at various times in the menstrual cycle (proliferative, $\mathrm{n}=7$; early secretory $=22$; mid-secretory, $\mathrm{n}$ $=13$; late secretory $=6$ ). Some of these samples were obtained in women undergoing bilateral tubal ligation, each found to be free of endometriosis at laparoscopy. The 13 mid-secretory samples were obtained in fertile controls that were recruited and paid for their participation. In addition, 19 mid-secretory endometrial biopsies were obtained from women with infertility that subsequently had endometriosis documented by laparoscopy. Each of these endometrial samples were selected because they lacked epithelial expression of the alpha v/beta 3 integrin, despite having normal, "in phase" histologic changes consistent with day 21 to 24 of the menstrual cycle, according to the dating criteria of Noyes et al [22]. All mid-secretory samples were obtained and timed to the urinary LH surge (Ovuiquick, Quidel, San Diego, CA). All samples were formalin-fixed and paraffin embedded. Histologic stage (endometrial dating) was assigned by two of the investigators (RAL and BAL). Samples were eliminated from further consideration if there was evidence of histologic delay that exceeded 3 days compared to the expected endometrial dating based on urinary LH testing. The acquisition and use of human tissue for this study was approved by the Institutional Review Board at the University of North Carolina at Chapel Hill and Greenville Hospital System, Greenville, SC.

\section{Immunohistochemistry}

Immunostaining for ER-alpha was performed on 5-to $6-\mu$ sections of formalin fixed, paraffin-embedded endometrial biopsies using the Vectastain Elite ABC kits (Vector Laboratories, Inc., Burlingame, CA). Diaminobenzidine (Sigma, St. Louis, MO) was used as the chromagen. Tissue sections were deparaffinized in xylene and hydrated in a series of graded ethanols. Following a rinse in PBS, $\mathrm{pH}$ 7.4 , endogenous peroxidase activity was quenched upon incubation for 30 min with $0.3 \% \mathrm{H} 2 \mathrm{O} 2$ in absolute ethanol, followed by a 10-min rehydration in PBS. Tissue sections were heated in a microwave for $12 \mathrm{~min}$ in antigen retrieval solution (10 $\mathrm{mm}$ citrate buffer) before incubation with primary antibody. After initial incubation with blocking serum for $30 \mathrm{~min}$ at room temperature (4\% normal goat serum), sections were incubated with mouse monoclonal antibodies against human ER-alpha (Novocastra, New Castle upon Tyne, UK) overnight at $4 \mathrm{C}$. Negative controls were analyzed on adjacent sections incubated without primary antibody. Each primary antibody was serially diluted to achieve maximum sensitivity and specificity. A PBS rinse was followed by treatment of secondary antibody consisting of biotinylated goat anti- 
mouse antibody for $30 \mathrm{~min}$. After this incubation, sections were washed and incubated with avidin:biotinylated horseradish peroxidase macromolecular complex for 60 min. Visualization of peroxidase was carried out by adding diaminobenzidine and incubated for $10 \mathrm{~min}$ to complete the reaction. As a final step, sections were counterstained with hematoxylin, dehydrated in a graded series of ethanols, cleared with xylene, and a coverslip placed over Permount for evaluation by light microscopy. The resulting staining was evaluated using a Nikon microscope (Tokyo, Japan), by a single observer (B.A.L.) without knowledge of the specimen's identity. Assessment of staining intensity and distribution was made using the semi-quantitative histologic score (HSCORE) system in the glandular and luminal epithelium and in the stromal compartment. HSCORE was calculated using the following equation: HSCORE: $\sum \mathrm{Pi}(\mathrm{i}+1)$, where i represents the intensity of staining ranging from 1,2 , or 3 , (representing weak, moderate or strong, respectively) and Pi representing the percentage of stained endometrial stromal and epithelial cells for each intensity, varying from 0-100\%.

\section{Cell Culture and Western Blot Analysis}

Ishikawa cells, the well differentiated endometrial carcinoma cell line, were obtained from Dr. M. Nishida (Kasumigaura National Hospital, Tsuchiura-shi, Ibarakiken, Japan) and maintained in MEM (Life Technologies, INC., Grand Island, NY) containing 5\% charcoal stripped fetal bovine serum (FBS), 1\% pencillin-streptomycin (Life Technologies, INC., Grand Island, NY) and $2 \mathrm{mM} \mathrm{L-}$ glutamine (Life Technologies, INC., Grand Island, NY) at $37^{\circ} \mathrm{C}$ in the presence of $5 \% \mathrm{CO} 2$. The culture medium was changed every 2-3 days. This cell line contains a functional estrogen receptor and as evident by estrogeninduced alkaline phosphatase enzyme activity bioassay, has been successfully used as a measure of estrogenic activity in these cells $[23,24]$. Cells were treated in phenol red-free DMEM/F12 media with $0.5 \%$ heat-inactivated charcoal-stripped FBS, 1\% pencillin-streptomycin and 2 $\mathrm{mM}$ L-glutamine. Cells plated onto $100 \mathrm{~mm}$ dishes were exposed to medium alone (control) or medium containing $17 \beta$-estradiol $\left(\mathrm{E}_{2} ; 10^{-8} \mathrm{~mol} / \mathrm{L} ;\right.$ Sigma) and/or epidermal growth factor (EGF; $10 \mathrm{ng} / \mathrm{ml}$ ) individually or in combination with the estrogen antagonist, ICI 182780 (10-6 $\mathrm{mol} / \mathrm{L}$; Zeneca Pharmaceuticals, Wilmington, DE) or C225 antibody $(30 \mathrm{nM} / \mathrm{ml}$; monoclonal antibody that neutralizes the EGF receptor, provided by Imclone, Inc. (New York, NY). In other experiments cells were treated with and with E2 (10-8 $\mathrm{mol} / \mathrm{L}$; Sigma), estriol (E3; 10-8 $\mathrm{mol} / \mathrm{L}$; Sigma) or equimolar concentrations $\left(10^{-8} \mathrm{M}\right)$ of selective estrogen receptor modulators (SERMs: Clomiphene Citrate, Tamoxifen, Raloxifene) The time of exposure in each experiment was $72 \mathrm{~h}$.
For immunoblotting of Ishikawa cell extracts, cells treated as described above were harvested individually and cell pellets obtained from the respective treatments were resuspended in RIPA extraction buffer $(10 \mathrm{mM}$ Tris- $\mathrm{HCl}$ [pH 8.0], 10 mM EDTA [pH 8.0], $150 \mathrm{mM} \mathrm{NaCl,} \mathrm{1 \%} \mathrm{NP-}$ 40 , and $0.5 \%$ SDS) containing protease-inhibitor cocktail (Boehringer Mannheim, Indianapolis, IN). After centrifugation at $10000 \times \mathrm{g}$ for $10 \mathrm{~min}$, protein concentrations were determined using the Bio-Rad protein assay kit (BioRad Laboratories, Hercules, CA). Total proteins (100 $\mu \mathrm{g}$ from each treatment) were denatured in Laemmli buffer, electrophoresed on $10 \%$ SDS-containing polyacrylamide gel and transferred to nitrocellulose membrane. Blots were blocked for $1 \mathrm{~h}$ in TBST (20 mM Tris [pH 7.5], 137 $\mathrm{mM} \mathrm{NaCl}$, and $0.4 \%$ Tween-20) containing $10 \%$ nonfat dry milk. Blots were washed twice for 5 min each time in TBST, then incubated overnight with a 1:1000 dilution of monoclonal antibody against alpha v/beta 3 integrin (SSA6; a generous gift from James Hoxie, University of Pennsylvania, Philadelphia, PA) while rocking at $4^{\circ} \mathrm{C}$. The blots were then washed twice for $30 \mathrm{~min}$ each time with TBST, followed by incubation for $1 \mathrm{~h}$ at room temperature with peroxidase-conjugated anti-mouse IgG secondary antibody while rocking. After washing twice for 30 min each time with TBST, the immunoreactive protein complexes were detected by enhanced chemiluminescence (Amersham Pharmacia Biotech Inc., Piscataway, $\mathrm{NJ})$. The results depicted are representative of 2 independent experiments.

\section{Statistical Analysis}

Comparisons between treatment groups were analyzed using ANOVA with Scheffe's correction for multiple comparisons using 95\% confidence interval ( $\mathrm{p}<0.05$ ). Analysis was performed on a Dell PC with GraphPad Prism 4 software.

\section{Results}

The pattern of expression for ER-alpha changed throughout the menstrual cycle, as judged by immunohistochemistry. As shown in Figures $1 \mathrm{~A}-\mathrm{C}$ and $2 \mathrm{~A}-\mathrm{C}$, the temporal and spatial pattern of ER-alpha was dynamic, with increased expression in glandular, luminal, and stromal compartments in the proliferative and early secretory phases, and a subsequent decline in the mid to late-secretory phases. Based on HSCORE determinations, the expression of ER-alpha in all three cell types was significantly lower in the secretory than the proliferative phase. Luminal epithelium exhibited reduced ER-alpha immunostaining relative to glandular epithelium. Stromal cells also were devoid of ER-alpha immunostaining during the time of maximal uterine receptivity in normal fertile samples. Later in the secretory phase, ER-alpha immunostaining returned to the stromal compartment but little if any 
immunostaining was observed in the epithelium in normal fertile controls.

Women with endometriosis who exhibited an aberrant lack of the alpha v/beta 3 integrin, as a group exhibited a significantly higher level of ER-alpha expression in epithelial cells compared to normal fertile controls. Examples of this are shown in Figure 1D and 1E. A comparison of ERalpha staining intensity and distribution (HSCORE) is also shown in Figure 2D comparing glandular and luminal ER-alpha distribution only. Note the higher levels of ER-alpha immunostaining in both cell types in women with endometriosis and suspected defects in uterine receptivity compared to normal women during the midsecretory phase.

To understand the mechanism of the action of estrogen on beta 3 integrin expression, we used the hormone responsive, well-differentiated, Ishikawa cell line. These cells mimic the pattern of gene expression for endometrial epithelium and provide a model to study factors that regulate specific genes in human endometrium [23,25-29]. As shown in Figure 3, using western blotting analysis, we show that estrogen strongly inhibits the expression of the beta 3 integrin subunit in Ishikawa cells, while EGF significantly increases its expression. Blockade of the EGF receptor with a neutralizing antibody (C225) mitigates this effect by EGF. Likewise, $E_{2}$ counteracts the stimulatory effect of EGF on beta 3 expression. The absolute estrogen antagonist, (ICI 182780) released the inhibitor effect of estradiol on beta 3 integrin expression, as well. This experiment suggests that the beta 3 gene product is regulated in endometrial epithelium by dual mechanisms that includes both stimulatory and inhibitory components and that estrogen inhibition appears to be dominant over EGF stimulation.

If inhibitory factors block the expression of beta 3 integrin, we next asked how different estrogens or antiestrogens might compare as potential treatments for loss of the beta 3 integrin. To examine the effect of various selective estrogen receptor modulators to reverse this inhibitor effect of estrogen, we pretreated Ishikawa cells with estradiol and then added equimolar quantities of either the weak estrogen (estriol; E3), the SERMs clomiphene citrate, tamoxifen, raloxifene and the anti-esrogen ICI 182780. As noted in Figure 4, tamoxifen and clomiphene citrate did little to restore normal beta 3 integrin expression. ICI 182780 was the most potent anti-estrogen in terms of reversing inhibition of beta 3 protein. Surprisingly, raloxifene was a fairly potent anti-estrogen in the endometrial cells, as it induced reasonable inhibition of the negative effect of estradiol on beta 3 integrin expression in Ishikawa cells.

\section{Discussion}

Estrogen action has traditionally been considered mitogenic and stimulatory in most target cells. During the proliferative phase, estrogen stimulates a large number of genes including c-fos and c-jun, cell cycle proteins and the estrogen receptor itself $[30,31]$. Exposed to unopposed estrogen, the endometrium undergoes hypertrophy and hyperplasia and eventually risks becoming neoplastic in the absence of cyclic progesterone exposure. As shown in the present study, estrogen appears to inhibit expression of specific proteins, a role we would argue is confined to select genes that are expressed during the window of implantation. While estrogen is a major hormone in the proliferative phase, it was previously argued that estrogen is unnecessary for the normal development of the secretory phase endometrium [32]. In our view, the disappearance of ER-alpha at the time of implantation as seen in most mammalian species, argues that continued ER-alpha expression may be detrimental to the development of uterine receptivity, or at least a sign of other dysfunction in the endometrial cycle.

Based on expected steroid receptor changes, the loss of ER during the mid-secretory phase provides a time in the cycle when mitoses cease and implantation occurs. In this study we documented, again, this decline in ER-alpha that has previously been described $[3,4]$. Such changes in steroid receptors may account for the four stages of the endometrial cycle as defined by recent DNA microarray studies [10]. In the first, estrogen works alone to stimulate ER-alpha and PR isoforms and to increase expression of a host of genes necessary for cell division and tissue growth. With ovulation, in the early secretory phase, progesterone acts to halt cell division and to induce secretory changes. In the third (mid-secretory) phase, ER-alpha largely disappears, providing for the first time, the opportunity for progesterone to act alone, specifically targeting the stroma [3]. The stroma contributes paracrine activity in response to progesterone, stimulating epithelial gene expression indirectly [16]. During the late luteal phase, ER-alpha appears to return to the stromal compartment, reflecting the time of sloughing and regeneration that will soon follow if pregnancy does not occur.

The elevation in ER-alpha that we describe in this study, corresponds to the lack of beta 3 integrin in selected patients with endometriosis. We described similar findings in women with polycystic ovarian syndrome (PCOS). This is another condition associated with infertility and pregnancy wastage. While ER-alpha is elevated in PCOS and beta 3 levels are low, the pathophysiology may be quite different between the two diagnoses. In the former, chronic estrogen may alter the complement of steroid receptor coactivators that are present; in endometriosis, elevations in aromatase have been described, possibly 

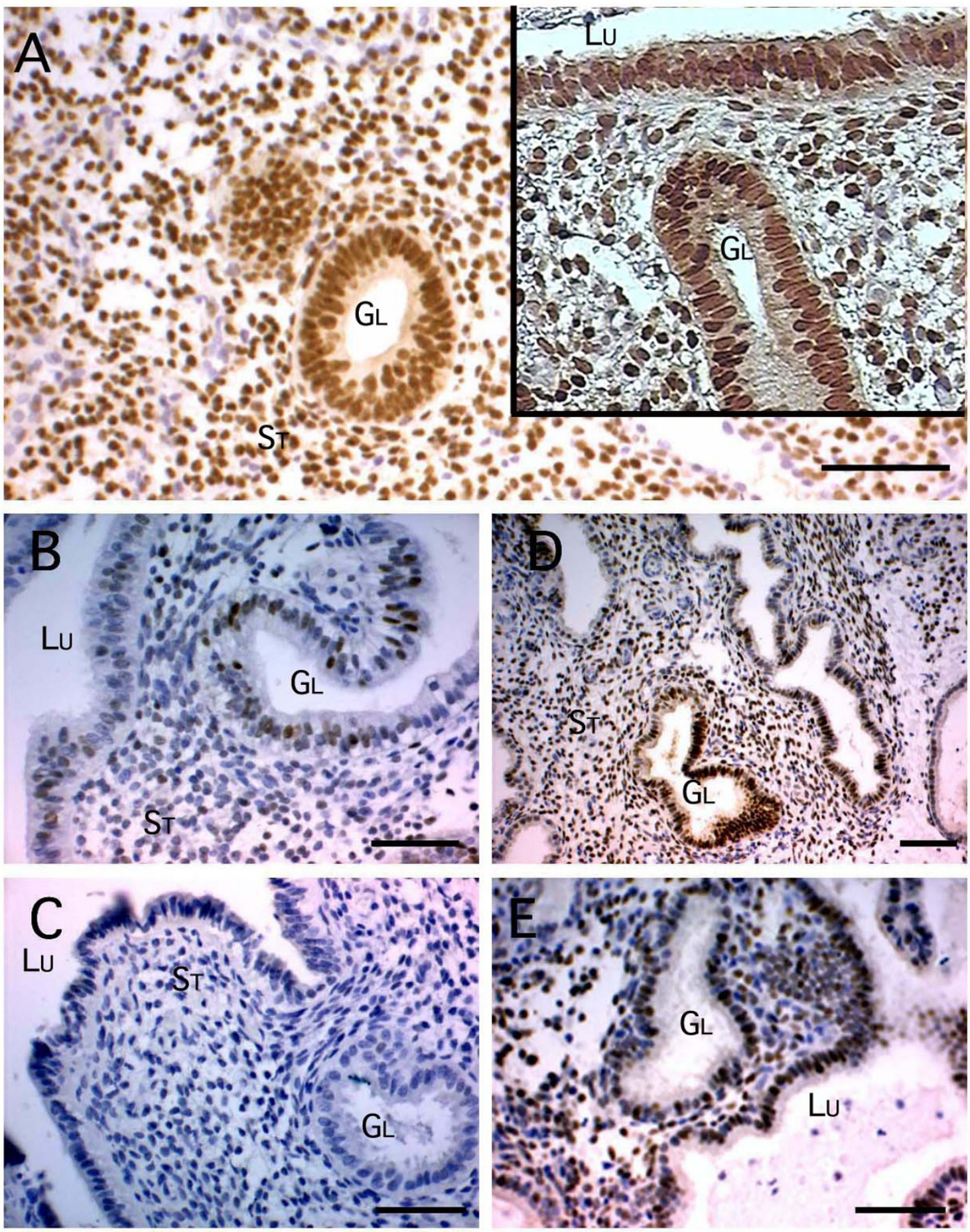

Figure I

Immunohistochemistry of ER-alpha in normal cycling women from the proliferative with inset showing luminal epithelium (A), early secretory $(B)$ and mid-secretory $(C)$ endometrium. Other samples from the mid-secretory endometrium from women with endometriosis shows increased and inappropriate expression of the ER-alpha protein in glandular and stromal compartments ( $D$ and $E$ ) compared to normal mid-secretory endometrium (C). Bar $=50 \mu \mathrm{m}$. 
A

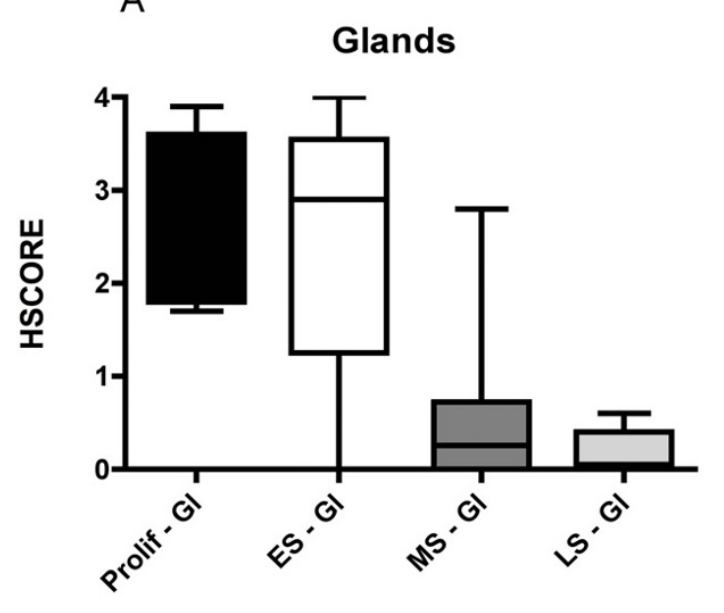

C

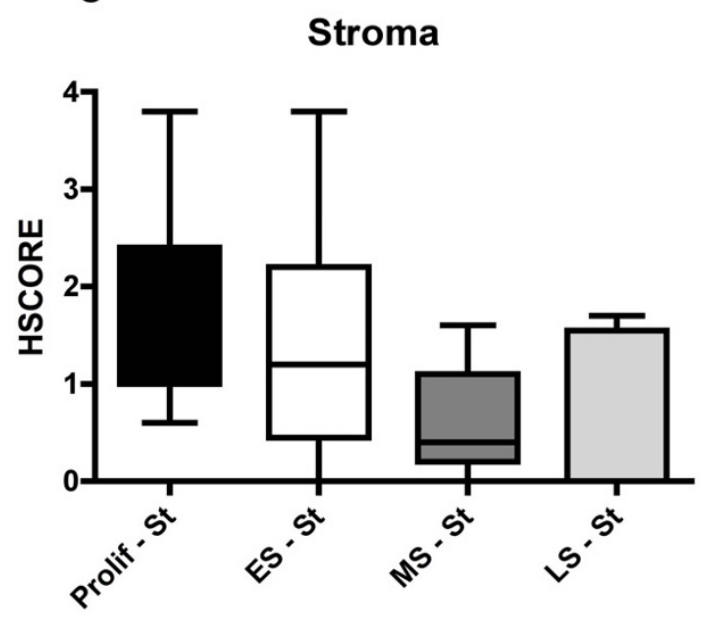

B

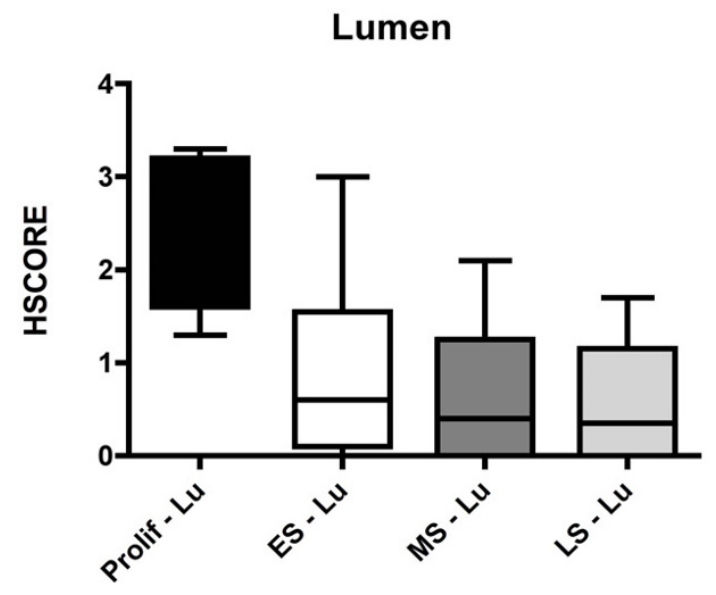

D Normal vs. Endometriosis

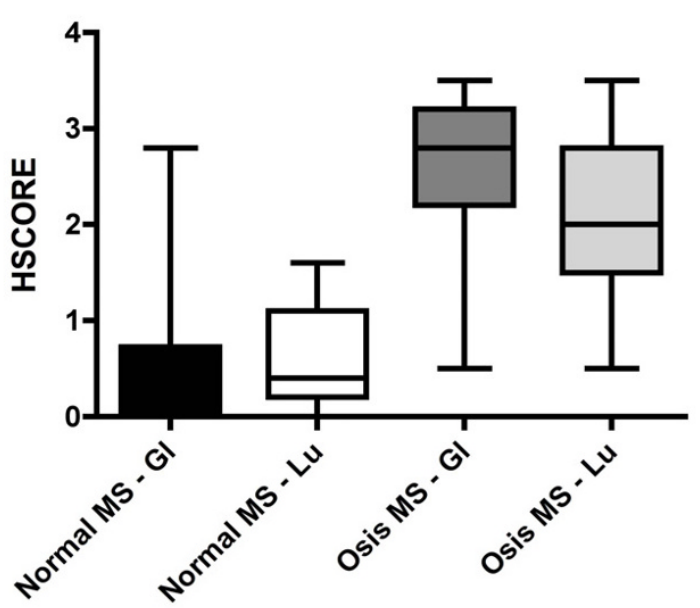

Figure 2

Box and whisker plots are shown depicting the semi-quantitative immunohistochemical staining (HSCORE \pm SD) for ER-alpha in normal women throughout the menstrual cycle in proliferative, early, mid and late secretory glandular (A) and luminal (B) epithelium and in stroma (C). In a separate analysis, glandular and luminal ER-alpha HSCOREs were compared between normal fertile mid-secretory endometrium and similar samples in women with endometriosis and suspected defects in uterine receptivity (D). Significance was based on ANOVA with Bonferroni correction; $*=p<0.01$, ** $=p<0.001$. Abbreviations in the figure: Prolif = proliferative phase, $\mathrm{ES}=$ early secretory, $\mathrm{MS}=$ mid-secretory, $\mathrm{LS}=$ last secretory, $\mathrm{gl}=$ glandular epithelium, $\mathrm{St}=$ stroma, $\mathrm{LU}=$ luminal epithelium, Osis = endometrium from women with endometriosis. Note that the horizontal bars in the box and whisker plots designate the $10^{\text {th }}, 25^{\text {th }}, 50^{\text {th }}, 75^{\text {th }}$, and $90^{\text {th }}$ percentile distribution of the data and standard error bars are not shown in this figure. 


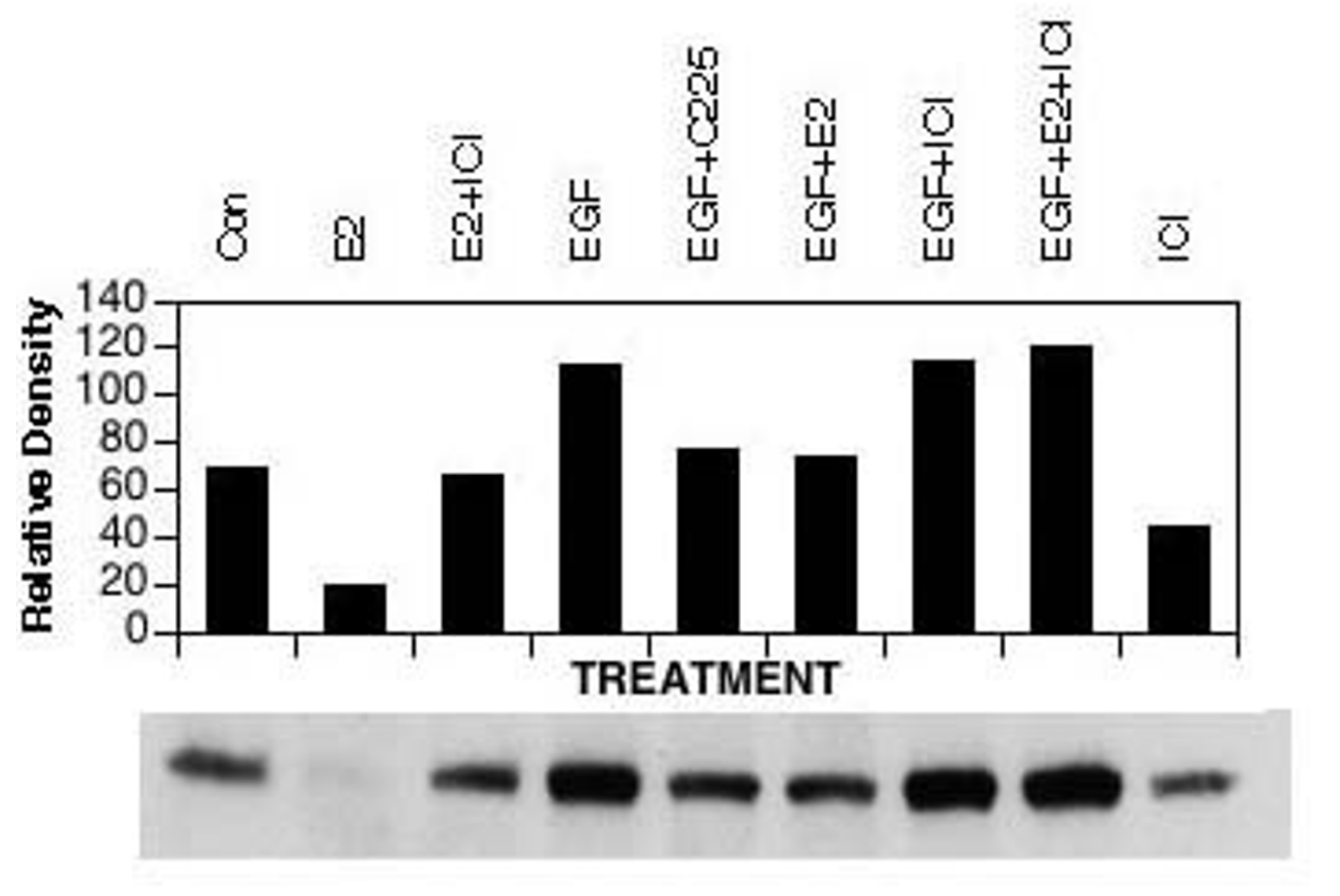

Figure 3

Western blot for beta 3 integrin expression in Ishikawa cells treated with no treatment (con), or three days of estradiol (E2; $\left.10^{-8} \mathrm{M}\right)$, estradiol plus the $10^{-6} \mathrm{M}$ pure antagonist ICl $182,780(\mathrm{E2}+\mathrm{ICl})$, epidermal growth factor $(\mathrm{EGF} ; 10 \mathrm{ng} / \mathrm{ml})$, EGF plus the EGF receptor antagonist antibody C225 (EGF + C225), EGF + ICI, EGF + E2 + ICI and ICl alone.

raising the local production of estrogen. Alternatively, faulty progesterone receptors have been reported in this disorder. In this study, we document that ER-alpha is increased in women with suspected defects in uterine receptivity lacking the EGF stimulated and estrogen inhibited gene, beta 3 .

We suspect that there will be many genes other than beta 3 integrin subunit that are regulated in concert during implantation in response to EGF and the loss of ER-alpha. There are likely to be many other endometrial genes that are inhibited by E2 and, like the beta 3 integrin protein, are only expressed when ER-alpha is down-regulated around the mid-secretory phase. Conversely, any failure to down-regulate ER alpha in infertile women may predispose to altered gene expression, including failure to express essential proteins associated with uterine receptivity [19]. Such defects have been described in the endometrium of women with endometriosis $[33,34]$, luteal phase defect (LPD), and polycystic ovarian syndrom (PCOS) $[19,20,35]$, each of which is associated with either infertility or pregnancy loss.

What might account for the aberrant down-regulation of ER-alpha by the time of implantation in all of these different disorders? In LPD, the timing of ER-alpha down-regulation is delayed, perhaps due to inadequate progesterone levels in the serum [36]. For endometriosis patients, it is 


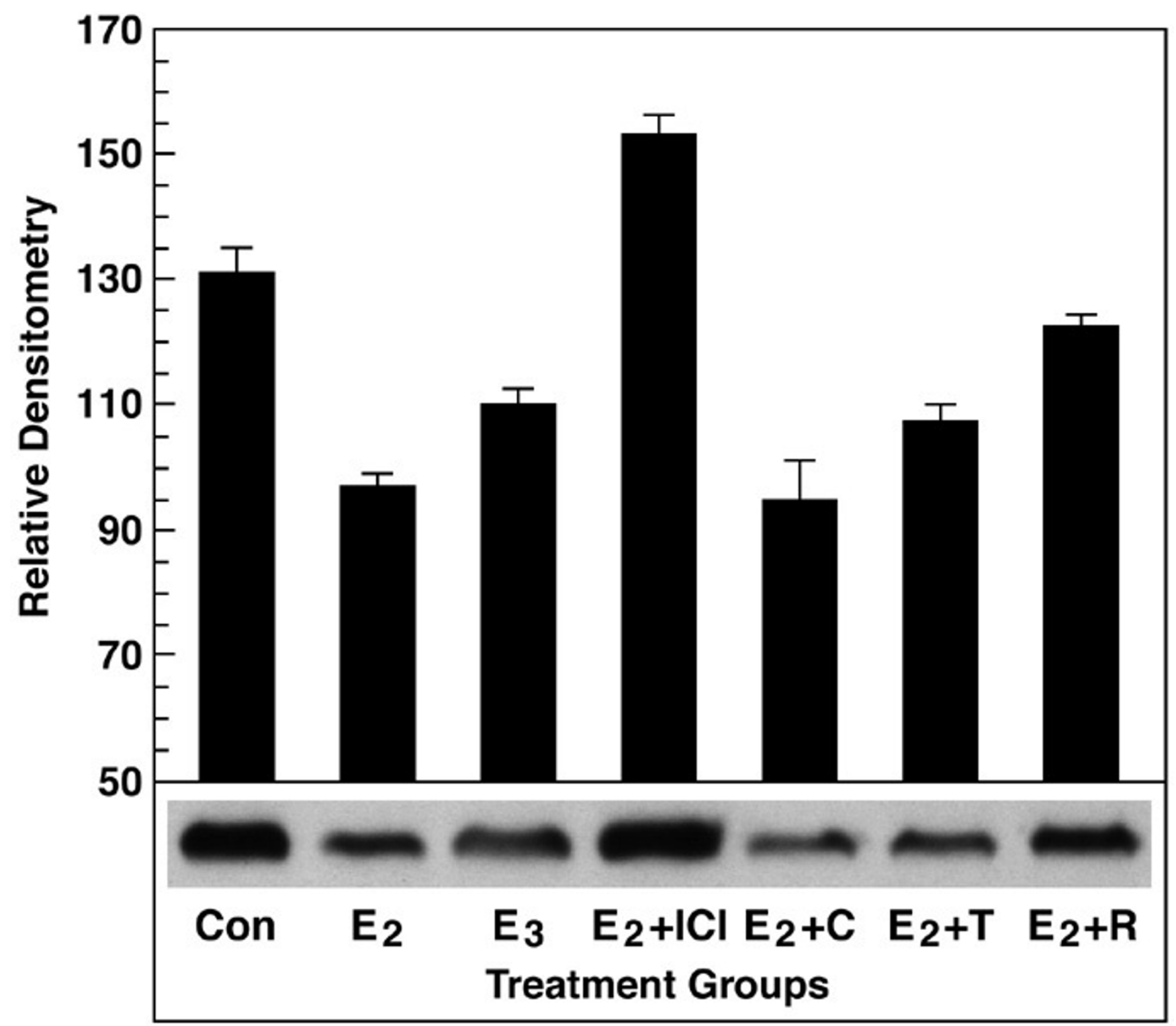

Figure 4

Western blot showing the effect of estrogen and anti-estrogens on the inhibition of the beta 3 integrin subunit in Ishikawa cells. In control cells, the beta 3 integrin was expressed while $10-8 \mathrm{M}$ estradiol reduced that expression significantly. E3 (estriol) was less potent than estradiol (E2) at inhibiting beta 3. Of the SERMS, in cells treated with E2 plus equimolar concentrations of other anti-estrogens and SERMs, a differential competitive antagonism occurred with the most potent antagonism by $\mathrm{ICl}$ 182,780. Raloxifene had an anti-estrogen effect on this well-differentiated endometrial cell line as well. Con = Control; E2 = estradiol; E3 + estriol; $\mathrm{ICI}=\mathrm{ICI}$ I82,780, $\mathrm{C}=$ clomiphene citrate; $\mathrm{T}$ = tamoxifen; $\mathrm{R}=$ raloxifene.

clear that the endometrium of women with endometriosis is different from normal endometrium [33,34,37]. An important difference between eutopic endometrium from women with and without endometriosis is also inappropriate expression of aromatase [38,39]. If aromatase increases local estrogen production within the endometrium, this might alter the balance between estrogen and progesterone and could therefore account for the elevation in ER-alpha observed in this study. Alternatively, increased IL- 6 has been demonstrated in the endometrium of women with endometriosis. IL-6 was recently shown in breast cancer cells to activate ER and this could lead to increased ER $\alpha$ expression $[40,41]$. Whether this effect is mediated through modulation of aromatase is not clear. In endometriosis patients, defects in the progesterone receptor have been postulated [37]. 
Loss of progesterone activity may result in the persistence of ER-alpha, since down-regulation of ER is one of the primary actions of progesterone. Finally, in PCOS, we suspect that elevated ER-alpha levels are also associated with a decrease in uterine receptivity. In this case, however, the failure to down-regulate ER-alpha may be due to a hypersensitivity to estrogen, as evidenced by the over-expression of steroid receptor coactivators and ER-alpha itself [20].

Thus, uterine receptivity defects may represent a common pathway for many women with infertility. The presence of ER-alpha in mid-luteal endometrium may be the best biomarker of a dysfunctional endometrium. Treatment of such defects might be designed to block the estrogen receptor or to correct the underlying cause of its overexpression. In women with elevated ER-alpha during the window of implantation, short-term treatment with antiestrogens may prove useful. If Raloxifene were used, for example, its anti-estrogenic blockage of ER-alpha activity may result in a normalization of biomarkers of uterine receptivity. To our knowledge, no one has suggested such a novel use of anti-estrogens, to stimulate uterine receptivity. Alternatives to anti-estrogens might also include the use of stronger progestins or the use of aromatase inhibitors. Only appropriately designed clinical trials will we be able to address these possibilities. Given the large number of women that might be affected, (e.g. PCOS, endometriosis or LPD) the potential benefits are substantial. A simple and direct treatment to restore normal uterine receptivity in the cycle of conception would truly be an enormous advance in our approach to women with implantation failure.

\section{Acknowledgements}

This article has been published as part of Reproductive Biology and Endocrinology Volume 4, Supplement I, 2006: Basic and applied biology of the primate reproductive tract: in honor of the career of Dr Robert M Brenner. The full contents of the supplement are available online at http://www.rbej.com/ supplements/4/SI.

\section{References}

I. Jensen EV: On the mechanism of estrogen action. Perspect Biol Med 1962, 6:47-59.

2. Brenner RM, West NB: Hormonal regulation of the reproductive tract in female mammals. Annu Rev Physiol 1975, 37:273-302.

3. Lessey BA, Killam AP, Metzger DA, Haney AF, Greene GL, McCarty KS Jr: Immunohistochemical analysis of human uterine estrogen and progesterone receptors throughout the menstrual cycle. J Clin Endocrinol Metab 1988, 67:334-340.

4. Press MF, Nousek GoebI NA, Bur M, Greene GL: Estrogen receptor localization in the female genital tract. Am J Pathol 1986, | 23:280-29|.

5. Press MF, Udove JA, Greene GL: Progesterone receptor distribution in the human endometrium. Analysis using monoclonal antibodies to the human progesterone receptor. $\mathrm{Am} J$ Pathol 1988, I 3 I: I I2-124.

6. Tan J, Paria BC, Dey SK, Das SK: Differential uterine expression of estrogen and progesterone receptors correlates with uterine preparation for implantation and decidualization in the mouse. Endocrinology 1999, 140:5310-5321.

7. Brenner RM, McClellan MC, West NB, Novy MJ, Haluska GJ, Sternfeld MD: Estrogen and progestin receptors in the macaque endometrium. Ann N Y Acad Sci 1991, 622:149-166.

8. Vermeirsch H, Van Den Broeck W, Coryn M, Simoens P: Immunolocalization of sex steroid hormone receptors in the canine uterine tube and their relation to sex steroid hormone concentrations. Reprod Fertil Dev 2002, 14:24I-250.

9. Richer JK, Jacobsen BM, Manning NG, Abel MG, Wolf DM, Horwitz $K B$ : Differential gene regulation by the two progesterone receptor isoforms in human breast cancer cells. J Biol Chem 2002, 277:5209-5218.

10. Talbi S, Hamilton AE, Vo KC, Tulac S, Overgaard MT, Dosiou C, Le Shay N, Nezhat CN, Kempson R, Lessey BA, Nayak NR, Giudice LC: Molecular phenotyping of human endometrium distinquishes menstrual cycle phases and underlying biological processes in normo-ovulatory women. Endocrinology 2006, 147:1097-II2I.

II. Ilesanmi AO, Hawkins DA, Lessey BA: Immunohistochemical Markers of Uterine Receptivity in the Human Endometrium. Microscopy Research and Technique 1993, 25:208-222.

12. Carson DD, Bagchi I, Dey SK, Enders AC, Fazleabas AT, Lessey BA, Yoshinaga K: Embryo implantation. Developmental Biology 2000, 223:217-237.

13. Wilcox AJ, Baird DD, Wenberg CR: Time of implantation of the conceptus and loss of pregnancy. N Engl J Med 1999, 340:1796-1799.

14. Lessey BA, Castelbaum AJ, Buck CA, Lei Y, Yowell CW, Sun J: Further characterization of endometrial integrins during the menstrual cycle and in pregnancy. Fertil Steril 1994, 62:497-506.

15. Lessey BA, Castelbaum AJ: Integrins and implantation in the human. Rev Endocr Metab Disord 2002, 3:107-I 17.

16. Lessey BA, Gui Y, Apparao KBC, Yuan LW, Young SL, Mulholland J: Heparin-binding EGF-like growth factor (HB-EGF) in the human endometrium: A potential paracrine role during implantation. Mol Reprod Dev 2002, 62:446-455.

17. Apparao KB, Murray MJ, Fritz MA, Meyer WR, Chambers AF, Truong $\mathrm{PR}$, Lessey BA: Osteopontin and its receptor alphavbeta(3) integrin are coexpressed in the human endometrium during the menstrual cycle but regulated differentially. J Clin Endocrinol Metab 200I, 86:499I-5000.

18. Lessey BA, Damjanovich L, Coutifaris C, Castelbaum A, Albelda SM, Buck CA: Integrin adhesion molecules in the human endometrium. Correlation with the normal and abnormal menstrual cycle. J Clin Invest 1992, 90: I88-195.

19. Lessey BA, Castelbaum AJ, Sawin SJ, Buck CA, Schinnar R, Wilkins B, Strom BL: Aberrant integrin expression in the endometrium of women with endometriosis. J Clin Endocrinol Metab 1994, 79:643-649.

20. Gregory CW, Wilson EM, Apparao KB, Lininger RA, Meyer WR, Kowalik A, Fritz MA, Lessey BA: Steroid receptor coactivator expression throughout the menstrual cycle in normal and abnormal endometrium. J Clin Endocrinol Metab 2002, 87:2960-2966.

21. Meyer WR, Castelbaum AJ, Somkuti S, Sagoskin AW, Doyle M, Harris $\mathrm{JE}$, Lessey BA: Hydrosalpinges adversely affect markers of endometrial receptivity. Hum Reprod 1997, 12:1393-1398.

22. Noyes RW, Hertig Al, Rock J: Dating the endometrial biopsy. Fertility and Sterility 1950, I:3-25.

23. Hata H, Kuramoto $\mathrm{H}$ : Immunocytochemical determination of estrogen and progesterone receptors in human endometrial adenocarcinoma cells (Ishikawa cells). J Steroid Biochem Mol Biol 1992, 42:201-2I0.

24. Littlefield BA, Gurpide E, Markiewicz L, McKinley B, Hochberg RB: A simple and sensitive microtiter plate estrogen bioassay based on stimulation of alkaline phosphatase in Ishikawa cells: estrogenic action of delta $\mathbf{5}$ adrenal steroids. Endocrinology 1990, I 27:2757-2762.

25. Castelbaum AJ, Ying L, Somkuti SG, Sun JG, Ilesanmi AO, Lessey BA: Characterization of integrin expression in a well differentiated endometrial adenocarcinoma cell line (Ishikawa). J Clin Endocrinol Metab 1997, 82: |36-| 42.

26. Croxtall JD, Elder MG, White JO: Hormonal control of proliferation in the Ishikawa endometrial adenocarcinoma cell line. J Steroid Biochem 1990, 35:665-669. 
27. Lessey BA, llesanmi AO, Castelbaum AJ, Yuan L, Somkuti SG, Chwalisz K, Satyaswaroop PG: Characterization of the functional progesterone receptor in an endometrial adenocarcinoma cell line (Ishikawa): progesterone-induced expression of the alphal integrin. J Steroid Biochem Mol Biol 1996, 59:31-39.

28. Lovely LP, Appa Rao KB, Gui Y, Lessey BA: Characterization of androgen receptors in a well-differentiated endometrial adenocarcinoma cell line (Ishikawa). J Steroid Biochem Mol Biol 2000, 74:235-24l.

29. Nishida M, Kasahara K, Kaneko M, Iwasaki H: Establishment of a new human endometrial adenocarcinoma cell line, Ishikawa cells, containing estrogen and progesterone receptors. Nippon Sanka Fujinka Gakkai Zasshi 1985, 37: I I03-IIII I.

30. Salmi A, Rutanen FM: C-fos and c-jun expression in human endometrium and myometrium. Mol Cell Endocrinol 1996, I I 7:233-240.

31. Kao LC, Tulac S, Lobo S, Imani B, Yang JP, Germeyer A, Osteen K, Taylor RN, Lessey BA, Giudice LC: Global gene profiling in human endometrium during the window of implantation. Endocrinology 2002, 143:2119-2138.

32. de Ziegler D, Bergeron C, Cornel C, Medalie DA, Massai MR, Milgrom $E$, Frydman R, Bouchard P: Effects of luteal estradiol on the secretory transformation of human endometrium and plasma gonadotropins. J Clin Endocrinol Metab 1992, 74:322-331.

33. Sharpe-Timms KL: Endometrial anomalies in women with endometriosis. Volume 943. Annals of the New York Academy of Science; $2001:|3|-\mid 47$.

34. Kao LC, Germeyer A, Tulac S, Lobo S, Yang JP, Taylor RN, Osteen K, Lessey BA, Giudice LC: Expression profiling of endometrium from women with endometriosis reveals candidate genes for disease-based implantation failure and infertility. Endocrinology 2003, I44:2870-288I.

35. Castelbaum AJ, Lessey BA, Lessey BA: Infertility and Implantation Defects. In Implantation Philadelphia: W.B. Saunders Company; 200I:427-446.

36. Fritz MA, Lessey BA, Fraser IS, Jansen RPS, Lobo RA, Whitehead MI: Defective luteal function. In Estrogens and progestogens in clinical practice Volume I. London: Churchhill Livingstone; 1998:437-453.

37. Igarashi TM, Bruner-Tran KL, Yeaman GR, Lessey BA, Edwards DP, Eisenberg E, Osteen KG: Reduced expression of progesterone receptor-B in the endometrium of women with endometriosis and in cocultures of endometrial cells exposed to 2,3,7,8tetrachlorodibenzo-p-dioxin. Fertil Steril 2005, 84:67-74.

38. Noble LS, Simpson ER, Johns A, Bulun SE: Aromatase expression in endometriosis. / Clin Endocrinol Metab 1996, 81: 174-179.

39. Kitawaki J, Kusuki I, Koshiba H, Tsukamoto K, Honjo H: Detection of aromatase cytochrome P-450 in endometrial biopsy specimens as a diagnostic test for endometriosis. Fertil Steril 1999 , 72:1100-1106.

40. Fontanini G, Campani D, Roncella M, Cecchetti D, Calvo S, Toniolo A, Basolo F: Expression of interleukin 6 (IL-6) correlates with oestrogen receptor in human breast carcinoma. $\mathrm{Br} J$ Cancer 1999, 80:579-584.

4I. Yamashita J, Hideshima T, Shirakusa T, Ogawa M: Medroxyprogesterone acetate treatment reduces serum interleukin- 6 levels in patients with metastatic breast carcinoma. Cancer 1996, 78:2346-2352.

\section{Publish with Bio Med Central and every scientist can read your work free of charge}

"BioMed Central will be the most significant development for disseminating the results of biomedical research in our lifetime. "

Sir Paul Nurse, Cancer Research UK

Your research papers will be:

- available free of charge to the entire biomedical community

- peer reviewed and published immediately upon acceptance

- cited in PubMed and archived on PubMed Central

- yours - you keep the copyright

Submit your manuscript here:

http://www.biomedcentral.com/info/publishing_adv.asp
BioMedcentral 